\title{
EDITORIAL
}

\section{Pulmonary arterial hypertension and the state of limbo}

\author{
S.P. Gaine* and M. Humbert ${ }^{\#}$
}

$\mathbf{T}$ he concept of limbo will be familiar to Catholic Christians. Traditionally, limbo was seen as place for the souls of infants dying before they had a chance to be baptised. It was a resting place that was neither heaven nor hell (fig. 1) [1]. The concept of a place that is neither heaven nor hell is also familiar to patients with pulmonary arterial hypertension (PAH). Prior to the discovery of new therapeutics for $\mathrm{PAH}$, patients had an untreated life expectancy of $<3$ yrs and were considered to reside in the "kingdom of the near dead" [2-4]. Nevertheless, despite substantial progress in our understanding of $\mathrm{PAH}$ and with new therapeutics, the current prognosis remains some distance from "heaven". While the majority of patients present with World Health Organization (WHO) functional class III symptoms, less than half will experience an improvement in functional class on a single oral agent and will, therefore, remain significantly disabled [5]. Furthermore, the 6-min walk distance improves, on average, by $\sim 40 \mathrm{~m}$ when initiated on oral agents, implying significant residual exercise limitation [6]. Indeed, despite the use of combination therapy including prostacyclin, $45 \%$ of patients with newly diagnosed idiopathic PAH will be dead within 3 yrs of diagnosis as so-called "incident cases" [7].

In this edition of the European Respiratory Review, VACHIÉRY and SIMONNEAU [8] emphasise the significant difficulties that remain regarding patients with the most severe form of PAH. Despite advances in diagnostic techniques and increased awareness about the condition, severely ill and difficult-totreat patients represent a significant proportion of the $\mathrm{PAH}$ population, including newly diagnosed patients [9]. VACHIÉRY and SIMONNEAU emphasise how current registry data show that the majority of patients with PAH are not diagnosed until their disease is in an advanced form, when up to $24 \%$ of patients are already in WHO functional class IV [8]. However, the authors also point out that it is the improvement in WHO functional class on treatment that is the stronger indicator of prognosis than baseline functional class. This provides a strong rationale for goal-directed therapy and the concept of treating to target $[10,11]$. Current therapeutic targets to achieve in PAH include patients having WHO functional class II symptoms or better, being able to walk $>380 \mathrm{~m}$ and having evidence of good right

\footnotetext{
*Dept of Pulmonology, Mater Misericordiae University Hospital, Dublin, Ireland. \#Université ParisSud 11, Service de Pneumologie et Réanimation Respiratoire, Hôpital Antoine Béclère, Assistance Publique Hôpitaux de Paris, Clamart, France.
}

CORRESPONDENCE: S.P. Gaine, Dept of Pulmonology, Mater Misericordiae University Hospital, Eccles Street, Dublin 7, Ireland. E-mail: sgaine@02.ie

Received: Oct 12 2010; Accepted: Oct 122010

PROVENANCE: Submitted article, peer reviewed. ventricular function on right heart catheterisation. It is recommended that combination therapy be initiated as necessary in order to achieve these goals [12]. Combination therapy, either initially in those with the most severe disease at presentation or sequentially for the less severe, are now part of $\mathrm{PAH}$ treatment guidelines [13].

Therefore, the goal is not just to stabilise the disease but to actively help our patients' ascent from the state of limbo. This is indeed a laudable goal, but how hard should we push to achieve it with currently approved therapies? There is a general consensus that more PAH therapy is better. Nevertheless, on a more cautionary note, recent registries are not demonstrating substantial and distinct differences in outcome between data collected from an amalgamation of smaller PAH centres with less use of prostacyclin and larger national centres [14-17]. Furthermore, lessons from cardiomyopathy literature may be important where improved haemodynamic parameters in response to therapy can still produce a worse outcome long term $[18,19]$. A composite end-point that seeks to look at outcome over time is therefore prudent in PAH. The focus in future clinical trials on the time-to-clinical worsening as an end-point offers the hope of a more realistic measurement of the effect of drug therapy on morbidity and mortality over time $[20,21]$.

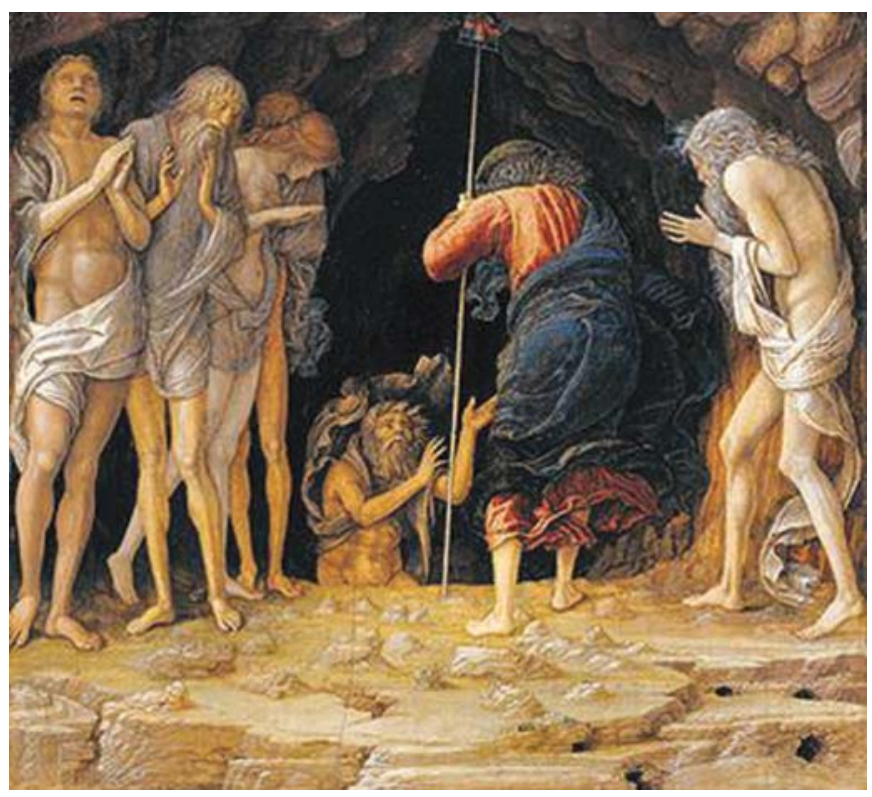

FIGURE 1. Descent into Limbo; Andrea Mantegna, Mantua, Italy. 1506. Image obtained from [1]. 
It remains to be seen what it will ultimately take for PAH patients to emerge from their current state of limbo. While we have made substantial progress, we will not emerge with our current therapies alone. New advances in our understanding of this disease and novel targets are required. The church concept of limbo was abolished by Pope Benedict XVI in 2006. We live in hope for a similar fate for limbo in PAH.

\section{STATEMENT OF INTEREST}

Over the past 5 years, S. Gaine has received speakers' honoraria and attended advisory board meetings with many of the companies involved in pulmonary hypertension including Actelion, Pfizer, GSK and Lung Rx/United therapeutics. He has received research grants from Pfizer and Actelion. M. Humbert has relationships with drug companies including Actelion, AstraZeneca, Bayer Schering, Chiesi, GSK, Lilly, MSD, Novartis, Nycomed, Pfizer and United Therapeutics. In addition to being an investigator in trials involving these companies, relationships include consultancy service and membership of scientific advisory boards.

\section{REFERENCES}

1 Mantegna A. Descent into limbo; 1506. [Painting]. http://en. wikipedia.org/wiki/File:MantegnaDescentLimbo.gif

2 D'Alonzo GE, Barst RJ, Ayres SM, et al. Survival in patients with primary pulmonary hypertension. Results from a national prospective registry. Ann Intern Med 1991; 115: 343-349.

3 Rich S, Dantzker DR, Ayres SM, et al. Primary pulmonary hypertension. A national prospective study. Ann Intern Med 1987; 107: 216-223.

4 Robin ED. The kingdom of the near-dead. The shortened unnatural life history of primary pulmonary hypertension. Chest 1987; 92: 330-334.

5 Sitbon O, Badesch DB, Channick RN, et al. Effects of the dual endothelin receptor antagonist bosentan in patients with pulmonary arterial hypertension: a 1-year follow-up study. Chest 2003; 124: 247-254.

6 Galie N, Brundage BH, Ghofrani HA, et al. Taladafil therapy for pulmonary arterial hypertension. Circulation 2009; 119: 2894-2903.

7 Humbert M, Sitbon O, Yaici A, et al. Survival in incident and prevalent cohorts of patients with pulmonary arterial hypertension. Eur Respir J 2010; 36: 549-555.

8 Vachiery J-L, Simonneau G. Management of severe pulmonary arterial hypertension. Eur Respir Rev 2010; 19: 279-287.
9 Habib G, Torbicki A. The role of echocardiography in the diagnosis and management of patients with pulmonary hypertension. Eur Respir Rev 2010; 19: 288-299.

10 Sitbon O, Galié N. Treat-to-target strategies in pulmonary arterial hypertension: the importance of using multiple goals. Eur Respir Rev 2010; 19: 272-278

11 Hoeper MM, Markevych I, Spiekerkoetter E, et al. Goal-oriented treatment and combination therapy for pulmonary arterial hypertension. Eur Respir J 2005; 26: 858-863.

12 Galiè N, Negro L, Simonneau G. The use of combination therapy in pulmonary arterial hypertension: new developments. Eur Respir Rev 2009; 18: 148-153.

13 Galiè N, Hoeper MM, Humbert M, et al. Guidelines for the diagnosis and treatement of pulmonary hypertension. Eur Respir $J$ 2009; 34: 1219-1263.

14 Humbert M, Sitbon O, Chaouat A, et al. Survival in patients with idiopathic, familial, and anorexigen-associated pulmonary arterial hypertension in the modern management era. Circulation. 2010; 122: $156-163$.

15 Benza LB, Miller DP, Gomberg-Maitland M, et al. Predicting survival in pulmonary arterial hypertension: insights from the Registry to Evaluate Early and Long-Term Pulmonary Arterial Hypertension Disease Management (REVEAL). Circulation 2010; 122: $164-172$.

16 Thenappan T, Shah SJ, Rich S, et al. Survival in pulmonary arterial hypertension: a reappraisal of the NIH risk stratification equation. Eur Respir J 2010; 35: 1079-1087.

17 Jardim C, Hoette S, Souza R. Contempoary issues in pulmonary hypertension. Eur Respir Rev 2010; 19: 266-271.

18 Packer M, Carver JR, Rodeheffer RJ, et al. Effect of oral milrinone on mortality in severe chronic heart failure. The PROMISE Study Research Group. N Engl J Med. 1991; 325: 1468-1475.

19 Cohn JN, Goldstein SO, Greenberg BH, et al. A dose-dependent increase in mortality with vesnarinone among patients with severe heart failure. Vesnarinone Trial Investigators. N Engl J Med 1998; 339: 1810-1816.

20 Galiè N, Rubin LJ, Hoeper M, et al. Treatment of patients with mildly symptomatic pulmonary arterial hypertension with bosentan (EARLY study): a double-blind, randomised controlled trial. Lancet 2008; 371: 2093-2100.

21 Hachulla E, Denton CP. Early intervention in pulmonary arterial hypertension associated with systemic sclerosis: an essential component of disease management. Eur Respir Rev 2010; 19: 314-320. 